\title{
IVOR LLOYD , TUCKETT
}

IVOR Lloyd TUCKETT died at his home in Cowes, I.O.W., "on November 28, 1942. Born in 1873 he was educated at Marlborough and Trinity College, Cambridge, and took his medical course at University College Hospital where he was house physician. He took the "College" diplomas in 1898 and proceeded M.D.Cantab. in 1910. After leaving University College Hospital he was house surgeon at Moorfields; and next returned to Cambridge to act as senior demonstrator of Physiology and assistant to the Downing Professor of Medicine. After a few years he was elected Fellow of Trinity College and he was also a Fellow of University College, London. Tuckett joined the Ophthalmological Society in 1917. He contributed papers on intra-ocular foreign bodies to our earlier volumes. Much of his literary work was physiological, and he was the author of an important paper in the Journal of Physiology on the structure of non-medullated nerve fibres.

\section{NOTES}

Deaths

IT is with very great regret that we learn from Dr. Burton Chance, of Philadelphia, that the following outstanding American Ophthalmologists died towards the end of last year; Edward Jackson, Luther Peter and William Shoemaker. We hope to publish notices of each in a later number.

Ophthalmological Society of the United Kingdom.

on Friday, April 30, and Saturday, May 1, Annual Congress, 1943 1943, at the Royal Society of Medicine. The subjects chosen for discussion are :

1. Friday morning, "Thyrotoxicosis in its Relation to Ophthalmology," to be opened by Dr. Russell Brain and Mr. L. H. Savin.

2. Saturday morning, "The Scientific and Clinical Aspects of Night-Vision, opened by Professor W. J. B. Riddell and AirCommodore P. C. Livingston, A.F.C.

There will be a joint clinical meeting with the Ophthalmological Section of the Royal Society of Medicine on Friday afternoon. Those wishing to show cases should notify Mr. A. J. B. Goldsmith, 15, Devonshire Place, W.1. Those who wish to read papers or to take part in the discussions should inform Mr. Frank Law, 36, Devonshire Place, W.1, as soon as possible. There will be no official dinner. Arrangements regarding hotel accommodation should be made by members in good trme. 